\title{
簡単な全下顎堤形成術について
}

\author{
吉沢信夫・嶋田均一・楊井孝・山崎博嗣 \\ 宇内 充・川島康・斎藤 力*・高橋庄二郎*
}

\section{A simplified method for total mandibuloplasty}

\author{
Nobuo Yoshizawa - Kinichi Shimada - Takashi YanaI - Hirotsugu YamazaKI \\ Takashi UnaI - Yasushi Kawashima - Chikara SaIto* - Shojiro TaKahashi*
}

緒言

近年，老人に対する柴科医療の需要が急激に高むって いる. 比較的頻度の高い多数歯の欠損に対する補緅, こ とに総義歯においては，その維持安定を良好ならしめる ため, 補緅学的面より種々の綿密な方法が講じられてい

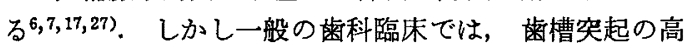
度萎縮の結果, 特に下䫇において口腔前庭と固有口腔と の境界がほとんど不明瞭となり，通常の補綴的手段では 咀緭機能の十分な回復の得られない症例が多くみられ る.

歯槽突起の高度な萎縮を示す症 例に対して, 安定 性のよい義荬を調製するために行われる歯慒堤形成術 は，欧米では従来よりかなり高い頻度で実施されてい

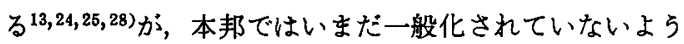
に思われる.このようなことは主として日本人と欧米人 の食生活の相違に起因するものではないかと想像され る. しかし最近, 日本人の摄取する食品も漸次欧米人の それに近づきつつあり，しかも平均寿命の延長とともに 老人の人口比率が次第に高まってきている。 したがっ て, 本邦でも歯槽堤形成術の適応例は, 今後ますます增 加してくるるのと考党られる。

われわれは数年来, 下顎歯槽堤の広範, 高度な萎縮症 例に対して, Obwegeserの発表した中間層植皮を用いる 全下買是形成術 ${ }^{11,12)}$ ならびに全層粘膜移植を行らObwe-

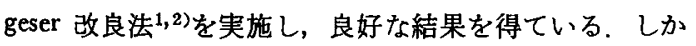
し, これらの方法は手術操作が複雑で, 手術的侵襲む大

東京宷科大学市川病院 粕科（主任：川島 康教 授)

Department of Dentistry, Ichikawa Hospital, Tokyo Dental College (Chief: Prof. Yasushi Kawashima)

* 東京菌科大学口腔外科学教室第 2 講座（主任 : 高 橋庄二郎教授)

Second Department of Oral Surgery, Tokyo Dental College(Chief: Prof. Shojiro Takahashi) 受付日：昭和52年11月 8 日
きくなりやすい欠点がある.

そこで最近われわれは，舌側において Trauner の発

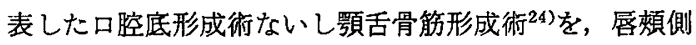
に Obwegeser の発表した粘膜下道槽堤形成術, 10)を行 5全下㴿堤形成術を実施し, 良好な結果を得ているの で, 本手術法の概要について報告する.

\section{手 術 術式}

本手術は, 舌側における口腔底形成術, 唇頓側におけ る粘膜下歯槽是形成術ならびに新しく形成される歯兓口 腔底粘膜および敬煩移行部保持の 3 部よりなる.

本手術は, 鼻腔插管による気管内麻酔下に, 塩酸エピ レナミン含有の局麻剂を手術部に注入し, 数分間経 過 後3), まず図 1 のごとく 1 側の臼後三角部前縁より他側 臼後三角部前縁にわたって歯兓口腔底粘膜移行部付近に 米慒頂と平行な切開を加兄，さらに両側臼後三角部前縁 より口腔底粘膜の方向へ約 $1 \mathrm{~cm}$ の縦切開を加える. 次 いで顎骨体部の骨膜上剥離と顎舌骨筋付着部の剥離を行 5. 顎舌骨筋付着部の豩離は, 後方における舌神経批よ び動・静脈の損傷を避けるため，鋭利なメスによる切離 を行うことなく手指によって鈍的に行う。すなわち骨体 部に近い口腔底上にガーゼ片を技き，その上から手指を もって口腔底を䅡下部に向かって強く圧迫する．この操 作によって䫇舌骨筋付着部が容易に剥離され, 出血もき わめて少ない，前雪部の舌側下額体に付着するオトガイ

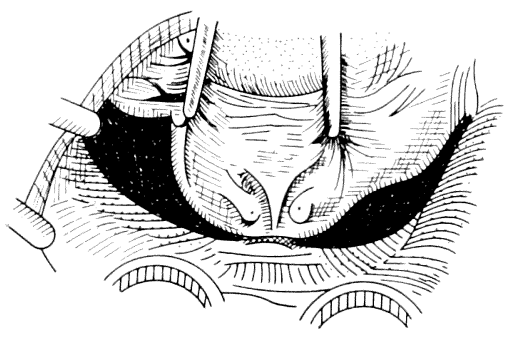

図 1 口腔底形成術における跑口腔 底粘暯移行部付近の切開 


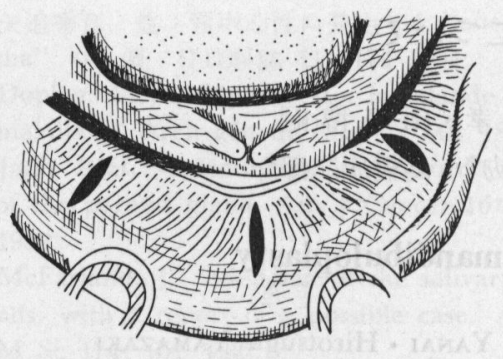

図 2 粘膜下口腔前庭形成術に扣ける縦切開

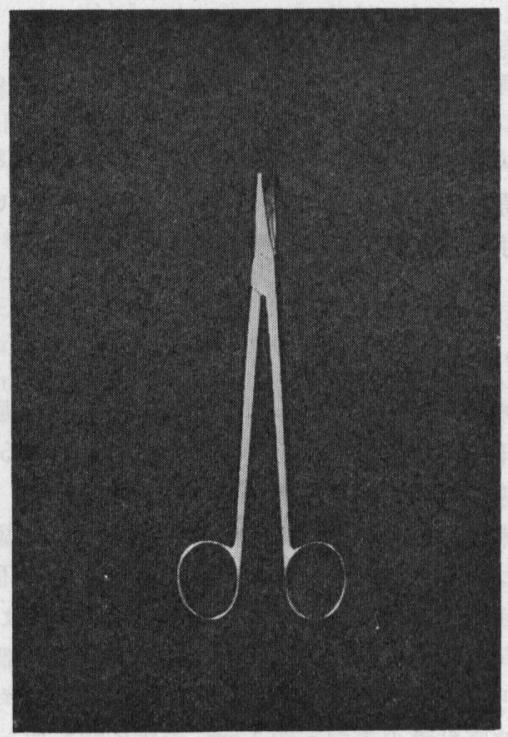

写真 1 粘膜下歯橝堤形成術に用いる剪刀

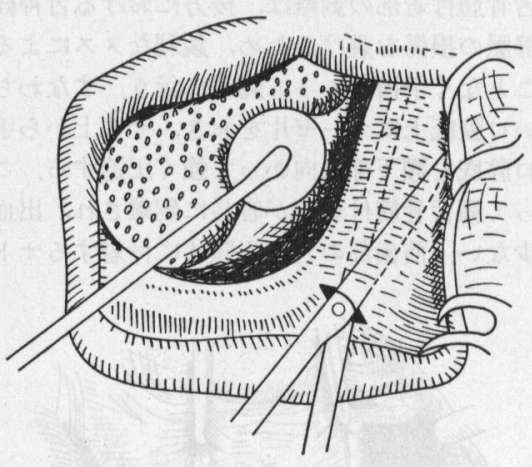

図 3 剪刀による粘膜下口腔前庭形成

舌筋およびオトガイ舌骨筋に対しては，舌の運動障害若 起を防止するため，上部执よび左右端部を鋭利なメスで わずかに切離するに止める。

唇煩側歯槽堤に対する処置としては，図2 のごとく正
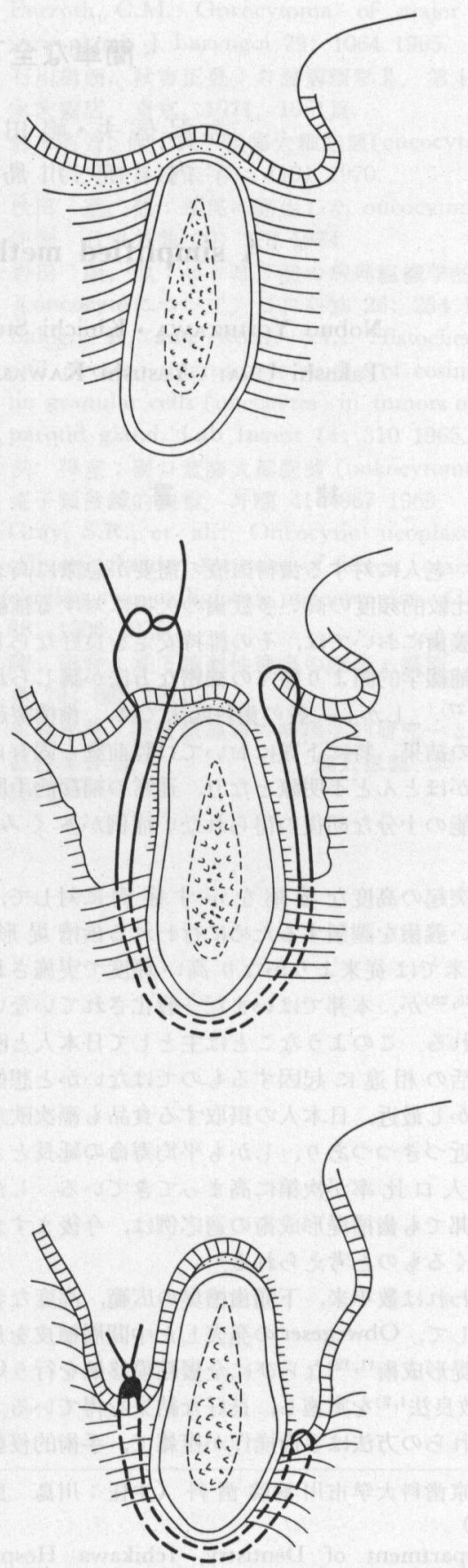

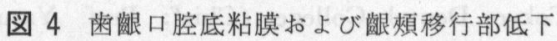
のためのナイロン糸による維持縫合

中部およびオトガイ孔付近における粘膜に対して縦切開 を加えオトガイ孔ならびにオトガイ神経血管束を確認 したのち，各切開創から写真1のごとき先端の鈍な剪刀 
を挿入して粘膜下をできるだく広く剝離し，次いで骨膜 上槑離ならびに前歯部に拁けるオトガイ筋および口輪筋 付着部，日歯部に括ける煩筋付着部などを切離する（図 3).この際，オトガイ神経血管束を損儩しないように 注意する。

以上の操作を終えたならば，口腔底粘膜切縁にやや太 目のナイロン系を数本通し，これを mandibular awl を 用いて皮演切開を行らことなく，下䫇下縁を通って新し く形成される眼頖移行部付近の粘膜上に出し， 6 号ネラ トンチューブ上で強く綘引して結紮する，この維持繨合

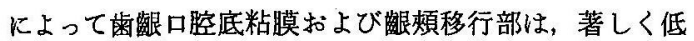
下される.なおこの際，唇頓側に批いて遊離された筋を 含む鏉組織を下方に強く王迫したのち縫合系の結禁を行 い，粘膜と骨膜とが密着するよ5に努める。 また，これ ら維持縫合糸の完全除去のため, 舌側に打いて各ナイロ ン糸のループ間にやや太目の絹系老通しておく，最後に 唇頓則における 3 つの綎切開の縫合閉鎖を行い，手術を 終了する（図 4).

症

\section{例}

以上のごとき手術を行ったものは51歳から71歳にいた る男 3 名, 女 4 名の合計 7 例で，いずれす繼発症なく， 良好な結果が得られた，以下，代表的な 1 例について述 べる。
患 者：59歳 男性.
初 診 : 昭和 50 年 5 月回。
主 訴: 勗嚼機能障害.

起始経過：数年前より下罰は無歯頸となり，開業医に て 3 度総義画の調製を行らも成功せず，䪽堤の萎縮著明

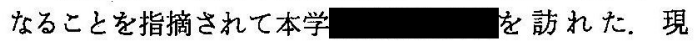
在, 食欲良好, 開口障害 $(-)$, 燕下障害 $(-)$ である が，硬固な食物の阻謝は障害されている。

既往歴：昭和32年, 狭心症発作を起こし, 現在む近医 に受診している。昭和33年扒よび昭和39年，交通事故に て入院. 昭和39年には事故の際, 耳出血岕り, 約 3 週間 入院治療をらけたとのことである。 また昭和 45 年，一酸 化炭素中毒浿遇している。

現 症：口空内は写真 2 に示すごとく下顎歯槽堤の萎 縮が著明で，口腔前庭と固有口腔との境界は不明膫とな ク，また歯槽頂と口腔底とはほぼ同じ高さにある。.X線 写真で両側下靧関節突起の陳旧性骨折と思われる所見が 琶められるが，これは怙そらく昭和39年の交通事故の際 のものと思われる。しかし下影運動の著しい異常は認め られず，下䫛被覆粘膜にも異常は諗められない(写真了).

\section{手 術：昭和50年 8 月日日。}

経鼻捜管による全身麻醉下に，まず舌側に対して既述 のごとき Trauner の方法に準した口腔底形成術を施行 したのち，頼側に颃いて写真 4 のごとく正中部，両側才

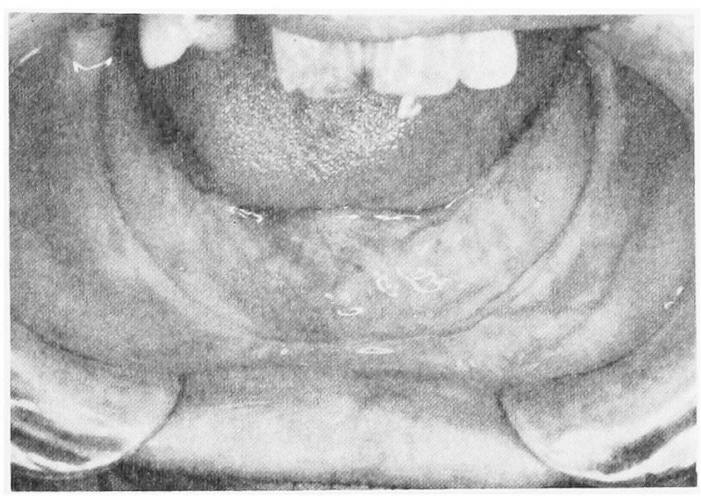

写真 259 歳の男性に扎ける術前口腔内所見

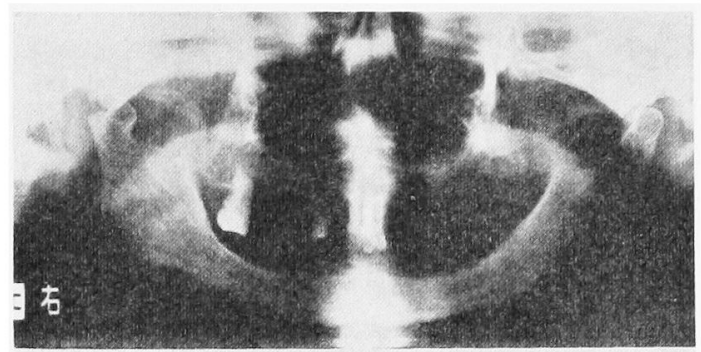

写真 3 写真 2 症例のオルソパントモグラフ

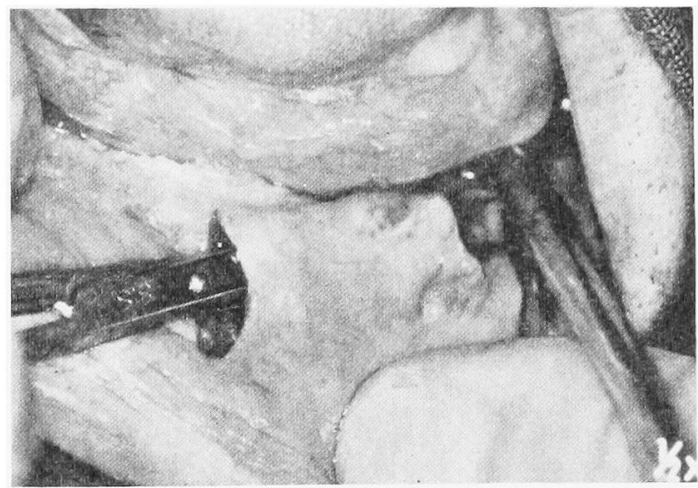

写真 4 正中より左オトガイ孔付近にかけてのロ腔 前庭形成術

トガイ孔付近に縦切開を加えこの部位より blind で粘 膜下剝離之骨膜上剝離，管付着部切離などを行った。 そ の後, 歯酿口腔底粘膜技よび兓頓移行部の維持縫合を行 った，写真 5 は手術終了時の所見である。

術後処置および経過：術後の経過は良好で，術後 2 週 間目に維持縫合系を除去した。すなおち口腔内の十分な 


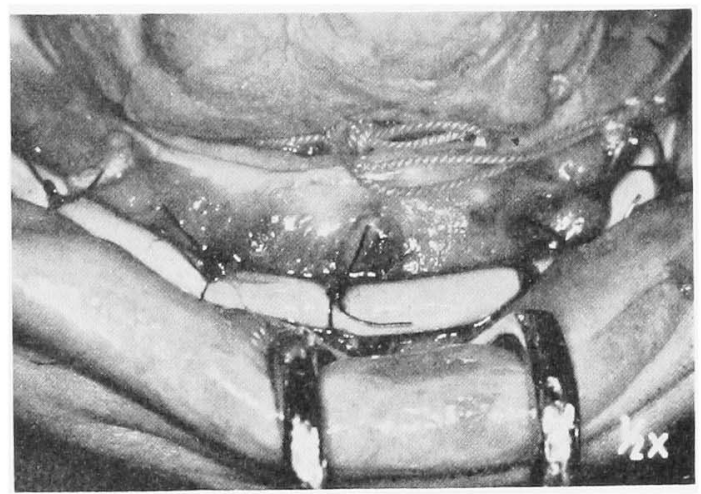

写真 5 手術終了時の所見

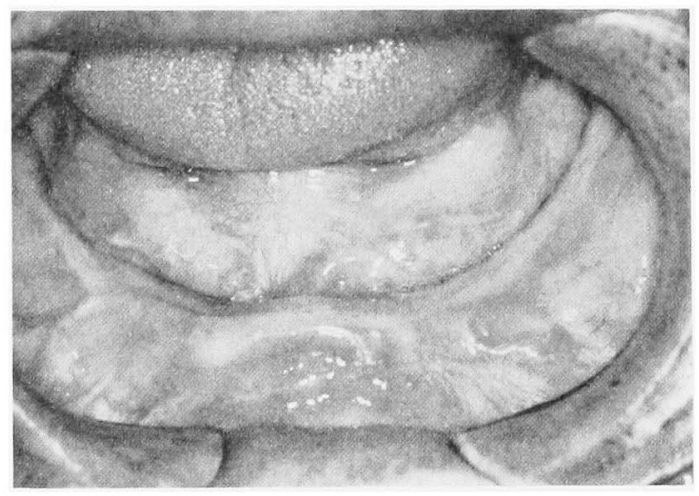

写真 6 術後 9 か月半の口腔内所見

清拭，消毒を行ったのち，ナイロン㭉の結節部を切除 し，舌側の綟糸をるちあげて完全抜糸を行い，続いてネ ラトンチュープも除去した. 写真 6 は術後 9 か月半の口 腔内所見, 写真 7 は術前術後における下顎模型（石离印 象）のモアレ縞法による等昌線写真である。亦た図 5 は 等高線写真より得られた両側第 1 大曰歯に相当する部位 の垂值断面図で，術前は点線，術後は実線で表わしてい る. 術後には口腔前庭および口腔底が下方に移動して, かなり高い歯槽堤の形成されていることがわかる。な お，本症例では術後 3 週目に義歯の rebase および休縁 の延長を行い，術後 3 か月目には新たな義崡の装着を行 った，術後における義歯の調製に際しては，靕上の方 法 ${ }^{6,7)}$ に準拠して印象採得を行い，口内法コシックアー チ描記による咬合採得を行った.

また，今回の 6 症例に対し，義齿の機能的検査の 1 つ として石原による筫分法 ${ }^{4}$ に準拠した生米の咀灀機能試 験を術前扣よび術後 6 か月目以後に行ったところ, 図 6 のごとく衍後における改善が認められた。

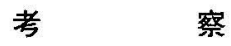

畨槽堤形成術には，歯槽骨の著しい萎樎によって低く

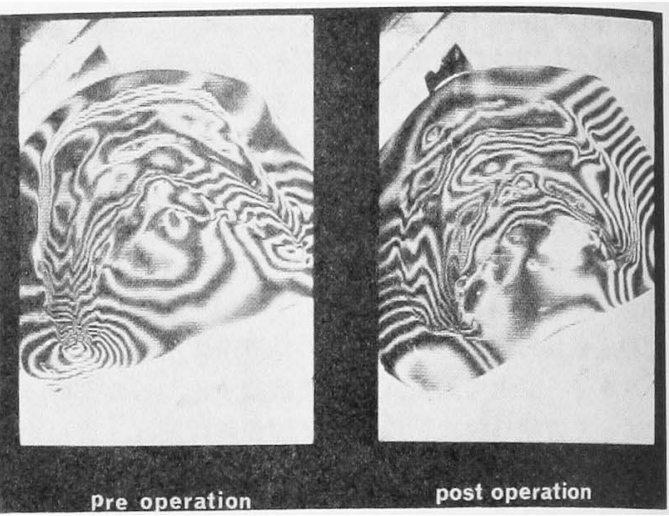

写真 7 術前街後における等高線写真

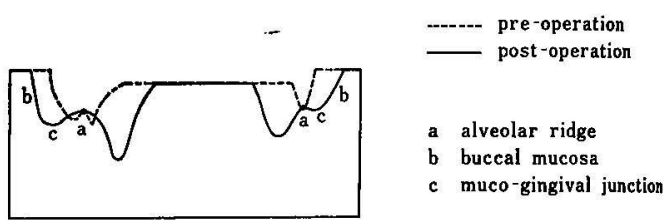

図 5 等高線写真の两側第 1 大臼歯部における前類 断面图

なった歯槽堤上に骨，軟骨，人工物などを移植または埋 久して歯㡟堤を高くする手術と，歯槽堤周囲の軟組織を 低下させて相対的に歯慒堤を高くする手術，すなわら画 槽堤扩大術の 2 つがある23,26).

前者は画槽堤の絶対的高さを增す点で積極的な手術法 であるが，手術操作がかなり複雑で，手術的侵襲す大き く，さらに移植された骨や軟骨は術後に吸収をきたしや すく，移植軟骨や人工物は下顎骨と結合せず，しかわ術 後口腔前庭形成術や口腔底形成術などの 2 次的手術を夷 施しなければならない。

これに対し, 後者の口腔前庭形成術および口腔底形成 術は，前者に比し手術操作和よび手術侵警の点で臨床的 応用筑囲が広いものと考えられる16).

雨槽堤の著しい萎縮を認め，義米の維持安定に支障老 きた寸頻度が高いのは下頡である。そのため著者らは数 年前より，下䫇の広筑な歯慒堤萎縮症例に対して Obwegeser の中間層植皮を用いる全下䝷堤形成術を主として 行ってきた. その後, 原法の遊離皮膚移植の代わりにロ 蓋あるいは頓粘膜から採取した全層粘膜を移植する方法

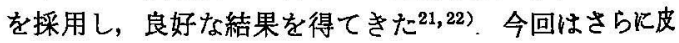
戍も粘膜も移㥀しない簡便な全下顎堤形成術を考案, 応 用してみた。

口腔前庭形成術ないし口腔底形成術には手術部の上皮 被覆法によって，1）2 次的上皮化法，2）隣接上皮利用 法，3）遊離植皮または粘膜移植法の3つがある1,2,5,8,14, 15,18 20) が，今回われわれの報告した方法は口腔底形成 術において 2 次的上皮化法を，口腔前庭形成術において 
20 回咀䑩における篩上\%

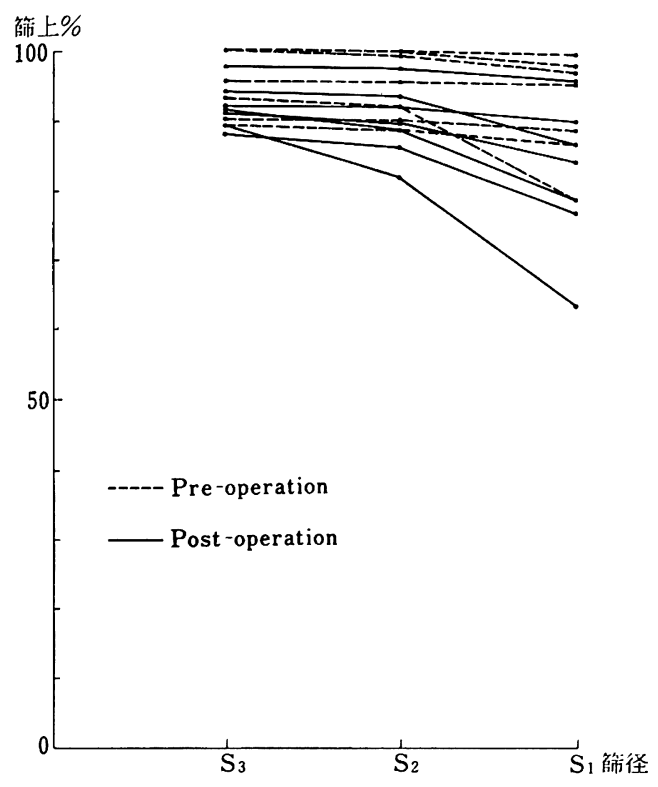

30 吅咀哂によおける篣上\%

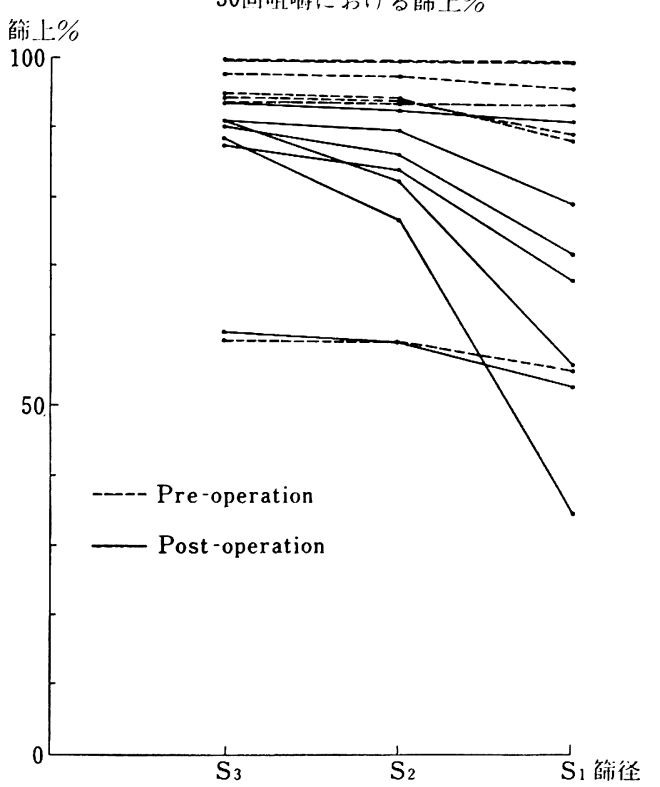

図 6 生米による咀嚼㙨能試験の結果

隣接上皮利用法を用いたものである。すなおち舌側にお いて Trauner の口腔底形成術を, 唇煩側において Obwegeser の粘膜下口腔前庭形成術を行らものである。舌 側では顎舌骨筋の切離を行い，口腔底粘膜を押し下げる ことによって，かなり広い範囲にわたって骨膜面が管出 するが, 同部の治癒は一般に良好で, 術後の relapse は きわめて少なかった。唇頓側における粘膜下口腔前庭形 成術は blind method であるため, ある程度熟練を要 し，また粘膜下剥離および骨膜上および筋付着部剥離を 十分に行わないと relapse が起こりやすいが, raw surface が残らないため, 治癒はきわめて良好であった.

要するに, われわれの方法は手術侵襲が少なく, 操作 も簡単で, 唇煩側に raw surface が残らないため迅速な 治癒が得られ， relapse 予防のためのレジン床装着を行 ら必要がなく, しかも relapse が比較的少ない特徵を有 し, きわめて応用価值の高い方法であると考えられる.

\section{結論}

下罘堤の萎縮が著明な症例に対して, 舌側に Trauner の口腔底形成術, 唇頓側に Obwegeser の粘膜下口腔前 庭形成術を行い, 口腔前庭にネラトンチューブをおき, 下顎下縁を通る維持縫合によって歯槽堤を形成する全下 頡堤形成術を報告した. 本手術によって, 植皮または遊 離粘膜移植を用いる方法とほとんど遜色のない下顎堤が 得られた。

\section{文献}

1) Hall, H.D.: Free grafts of palatal mucosa in mandibular vestibuloplasty. J Oral Surg 28: 5651970.

2) Hall, H.D.: Vestibuloplasty, mucosal grafts (palatal and buccal). J Oral Surg 29: 766 1971.

3）堀口精一：血管収縮剤による術中出血量の軽減 効果に関する研究。菻科学報 75：748 1975.

4) 石原寿郎：篩分法による咀謝能率の研究. 口腔 病学会雑誌 22: 2071955.

5) Maloneyl, P.L., et al.: Free buccal mucosal grafts for vestibuloplasty. J Oral Surg 30:716 1972.

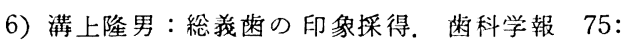
18891975.

7) 溝上隆男: 無菌顎の印象採得法. 料科学報 77: 1851977.

8) Müller, W.., et al.: Die Behandlung der Lappenfibrosen durch freie Schleimhauttransplantation. Dtsch Zahn-, Mund-u. Kieferheilk 57: 81971.

9) Obwegeser, H.: Neue Methoden der Alveolarkammplastik. Österr Ztschr Stomat 51:592 1954.

10) Obwegeser, H.: Die submuköse Vestibulumplastik. Dtsch zähnärztl Z 14: 6291959.

11) Obwegeser, H.: Die totale Mundbodenplastik. Schweiz Mschr Zahnheilk 73: 5651963. 
12) Obwegeser, H.: Zur Indikation für die einzelnen Methoden der Vestibulumplastik und Mundbodenplastik. Fortsch Kiefer-u. Gesichts Chir 10: 11965.

13) Pichler, H.u. Trauner, R.: Die Alveolarkammplastik. Ztschr Stomat 28: 6751930.

14) Propper, R. H.: Simplified ridge extension using free mucosal grafts. J Oral Surg 22: 4691964.

15) Shepherd, N.S., et al.. Fenstrated palatal mucosal grafts for vestibuloplasty. J Oral Surg 33: 341975.

16）塩田重利：口腔前庭扰よび口腔底形成訹一菌 槽堤形成術一。目医師会誌 29: 11976.

17) 末次恒夫, 他 : 水平影位决定の理論的背景につ いて。 日本菌科評論 377: 491974.

18) Steinhäuser, E.: Freie Schleimhautverpflanzung in der Mundhöhle-eine Massnahme zur Verbesserung des Prothesenhaltes. Schweiz Mschr Zahnheilk 78: 10461968.

19) Steinhauser, E.: Free transplantation of oral mucosa for improvement of denture retension. J Oral Surg 27: 9551969.
20) Steinhauser, E.W.: Vestibuloplasty-skin grafts. J Oral Surg 29: 7771971.

21）高橋庄二郎, 他: 遊離粘膜移植を用いる口腔前 庭形成術について。 日外誌 196851973.

22）高橋庄二郎, 他：植皮ならびに粘膜移植を用い る下顎堤形成術。畨科学報 74：201 1973.

23）高橋庄二郎，他：歯槽堤形成術の考方方と主な 㭪式. 日嵝医師会誌 27：463 1974.

24) Trauner, R.: Alveoplasty with ridge extensions on the lingual side of the lower jaw to solve the problem of a lower dental prosthesis. OS OM OP: 3401952.

25) Trauner, R., et al.: Alveoplasty with ridge extension. Brit J Oral Surg 8:70 1970.

26）宇賀春雄, 園山昇: 最新口腔外科小手術园 説. 医药薬出版, 東京, 1973，230頁.

27）柳田尚三，他：無潾顎の咬合高径の决定. 日本 齿科評論 377: 231974 .

28) Wassmund, M.: Über chirurgische Formgestaltung des atrophischen Kiefers zum zweche Prothetischer Versorgung. Vrtl Jhrschr Zahnhk. 47: 3051931. 